\title{
PREPARING UNIVERSITAS TERBUKA FOR A WORLD-CLASS UNIVERSITY THROUGH INTERNATIONAL RANKING SYSTEM
}

\author{
Diki (dikinian@mail.ut.ac.id) \\ Susy Puspitasari \\ Jasrial \\ Agus Djaya \\ Universitas Terbuka, Indonesia
}

\begin{abstract}
Universitas Terbuka (UT) aims at achieving a world class standard. As one of the criteria of a world class university is the world ranking, it is planned that the university should achieve a high position within the ranking. At present, the ranking systems are the Shanghai Jiao Tong University (SJTU) and Times Higher Education Supplement (THES). Positions of open universities in world university ranking are in the lower tier, both according to the THES and SJTU. However, ranking have a positive impact toward universities. Hence, it is possible that through the effort of achieving a high ranking, UT will have the benefit of improving its quality of services toward its stakeholders. If it is possible that ranking system criteria also fits the achievement of quality, there should be an advantage of gaining a high position in world ranking for UT. Therefore the question is how to improve the position of an open university within the international university ranking. Although the main priority of UT mission is to provide access of quality education to those who for some reason cannot attend conventional education, UT has opportunities for improving its rank among world university ranking. The advantage of the ranking is that it can support the effort to become a world class university. UT should improve international cooperation, both in teaching and research, while the research activities should be improved, both in its quality and its publications in accredited international journals. Lastly, the effort for achieving a high position in world ranking should not ignore the main mission of UT to provide access to education.
\end{abstract}

Keywords: open university, ranking system

Universitas Terbuka (UT) aims at achieving a world class standard. As the world ranking is one of the criteria of a world class university, it is planned that the university achieve a high position within the ranking. This aim was stated in the UT Operational Plan 2005-2010. Ranking is assumed to measure world-class status, accountability, and national competitiveness (Hazelkorn, 2009).

At present, the two most popular ranking systems are the Shanghai Jiao Tong University (SJTU) and Times Higher Education Supplement (THES). Each ranking system has its own criteria, which may put a particular university in a different rank. An exception is Harvard 
University which sits in highest position in each 2008 ranking. Most universities with high ranks are in US, UK, Japan and Europe.

Positions of open universities in world university ranking are in the lower tier, both according to the THES and SJTU. An example is the UK Open University, which is in the $200^{\text {th }}$ rank according to SJTU and the 401 to 500 in THES. Despite the fact that UK OU is the leading open university, its position is in the lower ranks compared to conventional universities. However, Hazelkorn (2009) stated that ranking has a positive impact toward universities. If it is possible that through achieving a high ranking, UT will also has the benefit of improving its quality of services toward its stakeholders. Therefore the question is how to improve the position of an open university within the international university ranking.

The question is based on the specific role of open universities, which are focused on providing accessible quality education to those who are less likely to attend conventional method of education (Salmi, 2009). Rather than focusing on achieving a high position in global ranking, open universities tend to optimize resources toward availability of services to those who had limited access to education.

Salmi (2009) proposed that a world-class university required concentration of talent, abundant resources and appropriate governance. Although good governance is encouraged in most open universities, the financial resources for the universities is not always sufficient to compete with conventional universities already sitting in higher national or international rankings. The author also suggested that international collaboration provided universities in developing countries with world class academic activities.

In Indonesia, UT is yet to join the THES ranking. In national ranking of universities, UT position is low compared to other universities, while UT is the only single mode distance learning university in the country. However, the university intended to become a center of excellence with a global standard. The paper discussed the way the university planned to achieve a global standard of excellence. It was good governance and international collaboration that were maximized by UT to improve quality.

\section{COMPARISON OF RANKING METHODS}

There are two ranking methods described in the article. The first is Shanghai Jiao Tong Academic Ranking of World Universities. Its criteria and percentage of each criterion are as follows:

- Quality of Education (10\%)

- Quality of Faculty

- Number of Nobel Prize/Field Medal (20\%)

- Number of Highly Cited Researchers (20\%)

- Research Output

- Number of Articles in Nature/Science (20\%)

- Number of Articles in Citation Index (20\%)

- Size of Institution (10\%) 
The SJTU suggests a more objective ranking method. The main indicators are the academic and research performance of faculty, alumni, and staff (Salmi, 2009). While there is a criterion of education quality, this is about the number of alumni of the university who have received the Nobel prize. The quality of faculty has two criteria. The first one is the number of academic staff who has received a Nobel prize. The second criterion is the number of highly cited research by academic staff included in each of 21 areas of science within the Thomson Scientific database. The research output also consists of two criteria. The first is the number of papers written by academic staff published in Nature and Science journal. The second criterion is the number of papers published in other highly-cited journals. (Billaut, Bouyssou, \& Vincke, 2009).

The SJTU does not have any indicator regarding the instructional quality (Levin, Jeong, \& Ou, 2006). Rather, it measures the quality through the number of academic staff getting the Nobel prize. This method is not directly related to the teaching activity (Marginson, 2007).

Another ranking system is Times Higher Education Supplement (THES). Below is the criteria and percentage of the ranking system:

- Peer Appraisal (40\%)

- Graduate Employability (10\%)

- Teaching Quality/SSR (20\%)

- International Students $(5 \%)$

- International Faculty (5\%)

- Research Quality/Citations per Faculty $(20 \%)$

THES put more emphasis of the ranking on research, comprising $60 \%$. Meanwhile, recruitment of international faculty and students also contributes to the assessment (Holmes, 2006). Aspects analyzed were student learning, community engagement/innovation and employability. Those data were taken from survey and peer review (Hazelkorn, 2009; Holmes, 2006).

Although research is a part of primary function of a university, teaching is not to be ignored by any university. Despite the fact that ranking put emphasis on research activities, the effort of UT to gain high ranking should prioritize the accessibility of its services toward those living in remote areas and having job and/or family responsibilities.

\section{CURRENT SITUATION OF UT AND EFFORTS TO IMPROVE POSITION IN WORLD UNIVERSITY RANKING}

The following description of the current situation of UT is based on primary points of ranking assessment Those points of assessment are research quality, graduate employability, teaching quality, infrastructure, and internationalization (Suparman, 2009).

1. Research quantity Based on 2008 data, the number of lecturers involved in research is 293, comprising $39 \%$ of 754 lecturers. The number is beyond the target of 2008.

2. Graduate employability 
Most graduate of UT are already employed. Typically, open university students are already working while studying.

3. Teaching quality

Teaching quality may be measured by the qualities of the tutors and learning materials. The tutors are recruited mostly from other universities. While the printed learning materials are developed in a team, consisting of subject matter expert, instructional designers and multimedia experts. The learning material are examined by external subject matter expert. They are lecturers from Indonesian universities other than the university of the learning materials author. It is to ensure clearness, completeness, system consistency, logic of the substance, and relevance to the substance and the educational level.

4. Infrastructure

The criteria of infrastructure for grading an open university is rather irrelevant. At the university, students study mostly at home or in the office. This is why the university does not provide much facility for student to study on campus. An example is that at the head office of UT, there are no classroom for students. Although regional offices have some classrooms, those are not intended for accomodating the whole student body.

5. Internationalization

As the university prioritize its services toward the Indonesian community, especially those who do not have access to tertiary education, the criteria is less relevant. Students are mostly Indonesian nationals. The learning materials are not in English, but in Bahasa Indonesia, that may be an obstacle for expanding UT services to foreign students. There are also some overseas Indonesian students, such as in Singapore or Saudi Arabia. Foreign students will be more likely to take the Indonesian Language Program for Foreigner (BIPA), which is still being prepared. The BIPA course will be launched in 2010. Apart from this , a joint postgraduate course with other South East Asian open universities is still under development, among which is the master program in ASEAN Studies, a joint program of UT and other ASEAN open universities.

The current situation at UT requires a plan for future improvement in terms of quality. At present, UT has an Operational Plan of 2005-2010 (Suparman, 2009), which includes targets for the improvement of quality, such as:

- UT will have Asian and world accreditation

- UT learning materials are recognized by other Asian open universities

- There is at least one tutorial service for $50 \%$ of the subject matter, and one online tutorial for $10 \%$ of all the subject matter taught.

- There is an examination and feedback mechanism for $100 \%$ of the subject matter.

- $20 \%$ of the academic staffs participate in research, and $5 \%$ of the researches are published in international journals.

- There are at least five continuing education programs in which one is taught in English.

- There are two national level community service programs, such as the participation in the illiteracy eradication program

- Expansion of services to cover every city/district throughout Indonesia. 
As we know, the present ranking system does not show that any open university has achieved high levels. Thus, some ideas to increase position on world ranking are mentioned, such as taking a larger set of indicators, improving the quality of the various indicators, and using multicriteria analysis (de Maret, 2007). The suggestion means that the present ranking system needs to be improved, in order to include characteristics of open universities. As the case of UK OU indicates, regardless of advancement within the university, the ranking system does not consider that open universities have a mission and a mechanism different from conventional institution.

The use of other criteria for distance education was also suggested in CHEA (2002). The specific criteria should include:

- Institutional Mission.

- Institutional Organizational Structure.

- Institutional Resources.

- Curriculum and Instruction.

- Faculty Support.

- Student Support.

- $\quad$ Student Learning Outcomes.

Those characteristics are not included in both SJTU and THES ranking system. Ideally, those criteria are included in the future world university ranking, so that any open university may achieve a better rank, compared to other universities.

On the other hand, the gap between distance education and conventional education is not as wide as it was previously. Online learning is used both in distance and conventional education. Internet enables student of conventional universities to contact teacher, access learning materials and submit assignments, even when students were adults and have jobs or family responsibilities (Park, 2005). This development brings about a common base for comparison of both modes of education. Thus, to some extent, open universities have to compete in terms of its quality of education with conventional universities.

In order to compete with other universities, mostly the conventional universities, open universities should improve their quality. Salmi (2009) suggested that upgrading an existing university to improve its ranking is possible. Hence, UT aims at achieving a better quality, eventually a better ranking. The main advantage is that it is the most economical. It is more economical to use the already available facility, organization, and human resources of the existing university. The disadvantages of upgrading an existing university are the difficulties to attract newer faculty members, to replace the governance within the similar regulatory framework, to initiate cultural reform, and require acceptance to replace the management (Salmi, 2009).

Research is one topic of ranking evaluation. In order to improve the ranking, improvement of research activity and publications is quite important. As mentioned previously, the number of research activity at UT is increasing. While the increase is a positive achievement, the 
publications in internationally accredited journals need to be improved. The publications are a key point in the ranking system (Holmes, 2006; Billlaut, et al., 2009)

Apart from a more active and well-published research, they need to be refocused from disciplinary into interdisciplinary-oriented research (Hazelkorn, 2009). Based on 2009 data, the number of interdisciplinary research funded by UT is 79 , almost twice the number of disciplinary research. It does not include the number of academic staff research funded by external institution.

One focus of improving quality in an open university is the quality of textbook (Park, 2005; CHEA, 2002). At UT, the textbook is the main learning media. Therefore, the quality of textbook is quite important. The UT Operational Plan of 2005-2010 includes external supervisor for each textbook. Moreover, the joint programs with other South East Asian open universities involve international academic staff to take part in developing learning materials.

Meanwhile, as the one criteria assessed within the ranking is international student and faculty, UT may achieve some level of improvement. Without compromising its focus on providing the domestic student since UT is a public university, new courses involves both faculty member and students from abroad. The ASEAN Studies course is intended for foreigners as well as Indonesian citizens. On the other hand BIPA is intended entirely for foreigners.

UT should consider that despite the focus on improving ranking, its main aim is providing education on a mass scale. It is apparent by the number of student, which are 487.000 in 2009. Park (2005) explained that overwhelming students' number might have detrimental effect toward an open university, though an open university is intended to provide mass education. A negative effect may be over-stretching the staff and resources to serve the students.

The focus on providing distance education is the primary mission of UT. While achieving the ranking is a way to improve quality, the management should be aware that a world class university requires abundant financial resources (Salmi, 2009). As a public university, the funding of UT comes from the government and tuition fee. In contrast, the funding of world class universities is not only from government and tuition fee, but also from research fund and endowment. Thus, a world class university has more flexibility in prioritizing activities, especially activities directly related to the ranking, while UT does not. Therefore, by becoming a state-owned legal entity, UT may have a greater autonomy for managing its budget.

\section{CONCLUSION}

Although the main priority of UT mission is to provide access of quality education to those who for some reason cannot attend conventional education, UT has opportunities for improving its rank among world universities. The advantage of ranking is that it can support the efforts to become a world class university. As the ranking system does not cover specific characteristics for distance education, UT needs to include other criteria. Therefore, the priority of the development plan still covers the typical needs of an open university (CHEA, 2002; Park, 
2005). The criteria, especially the curriculum and instruction, faculty support and student support are all very important.

UT should improve the international cooperation, both in teaching and research, with improved research activity, both in its quality and its publications in accredited international journals. Lastly, the effort for achieving a high position in world ranking should not ignore the main mission of UT which is to provide mass access to education.

\section{REFERENCES}

Billaut, Bouyssou, J.D., \& Vincke, P. (2009). Should you believe in the Shanghai ranking? An MCDM view, Retrieved July 10, 2009 from http://hal.archivesouvertes.fr/docs/00/38/83/19/PDF/ Shanghai_JCB_DB_PV.pdf.

CHEA, Council for Higher Education Accreditation. (2002). Accreditation and assuring quality in distance learning, CHEA Institute for Research and Study of Accreditation and Quality Assurance, CHEA Monograph Series 2002, Number 1. Retrieved July 10, 2009 from www.chea.org.

de Maret, P. (2007). Universities in the world: What for? In Sadlak, J. and Liu N.C. (eds) The world-class university and ranking: Aiming beyond status. Bucarest: UNESCOCEPES/

Shanghai Jiao Tong University (2007). Academic Ranking of World Universities. Graduate School of Education, Shanghai Jiao Tong University. Retrieved July 10, 2009 from http://www.arwu.org/.

Hazelkorn, E. (2009). Impact of global rankings on higher education research and the production of knowledge. Occasional paper No. 15.UNESCO forum on higher education, research, and knowledge. Retrieved July 10, 2009 from http://unesdoc.unesco.org/images /0018/001816/181653e.pdf.

Holmes, R. (2006). The THES university rankings: Are they really world class? Asian Journal of University Education (MARA University of Technology, Malaysia), 1/1, 1-14.

Retrieved July 10, 2009 from http://siteresources.worldbank.org/EDUCATION/Resources/2782001099079877269/547664-1099079956815/547670-1237305262556/WCU.pdf.

Levin, H.M., Jeong D.W., \& Ou D. (2006). What is a world class university? Retrieved July 10, 2009 from http://www.tc.columbia.edu/centers/coce/pdf_files/c12.pdf.

Marginson, S. (2007). Rankings: Marketing mana or menace ?, article presented at $16^{\text {th }}$ Annual New Zealand International Education Conference, 8-10 August 2007, Christchurch, New Zealand. Retrieved July 10, 2009 from http://www.cshe.unimelb.edu.au/people.staff_pages/Marginson/Marginson.html.

Park, D.J. (2005). Challenges facing the open university: The Case of the Korea National Open University. AAOU Journal, 1 (1), September 2005.

Salmi, J. (2009). The challenge of establishing world-class universities. World Bank, Washington, D.C. Appendix F. Retrieved August 10, 2009 from http://siteresources.worldbank.org/EDUCATION/Resources/2782001099079877269/547664-1099079956815/547670-1237305262556/WCU.pdf .

Suparman, A. (2009). Laporan Rektor 2009. Tangerang: Universitas Terbuka. 